\title{
Antioxidants and prooxidants in malnourished populations
}

\author{
BY DAVID I. THURNHAM \\ MRC Dunn Nutrition Laboratories, Milton Road, Cambridge CB4 $1 X J$
}

In recent years there has been increasing interest in the possibility that oxygen free radicals or 'reactive $\mathrm{O}_{2}$ species' (ROS), may in certain circumstances exert damaging oxidative effects on tissues and be responsible for aspects of disease pathology. In the developed world this interest has focused on cancer (Slater, 1984), rheumatoid arthritis (Blake et al. 1989), drug toxicity (Sherlock, 1986) and atherogenesis (Gey, 1986) and the cumulative effects of oxidative damage have also been implicated in aging (Harman, 1984).

In the Third World, cancer has also attracted attention particularly in connection with aflatoxin-contaminated foods, nitrosamines, betel nut (Areca catechu) chewing, various hydrocarbons in combustion gases etc., many of which may initiate cancer through free radical-forming mechanisms (Halliwell \& Gutteridge, 1985). It has also been suggested that kwashiorkor may be a product of free radical-initiated tissue damage in the malnourished child (Golden \& Ramdath, 1987) and that cerebral malaria may represent a breakdown in tissue defences against ROS produced by cell-mediated immune mechanisms (Clark et al. 1989).

In the present review, I will discuss those antioxidants in the blood of malnourished populations which prevent lipid peroxidation and those which quench radical products. The different ways of measuring total antioxidant capacity will be described and, as both chronic and acute infections are commonly present in malnourished populations, I will also discuss the influence of infection on the antioxidant-prooxidant equilibrium.

\section{ORIGIN OF FREE RADICALS IN BIOLOGICAL TISSUES}

There are a large number of foreign substances in our environment which when ingested and metabolized by man will produce free radical end-products, and some have been mentioned previously (Halliwell \& Gutteridge, 1985). It is believed, however, that there are three main sources of free radicals in biological tissues all of which give rise to superoxide (Dormandy, 1983):

(1) normal oxidative metabolism,

(2) microsomal cytochrome $\mathrm{P}_{450}$ activity, which is inducible by a variety of foreign compounds,

(3) the respiratory burst of stimulated phagocytes (Baboire, 1973).

The majority of superoxide formed is probably harmlessly removed by the action of superoxide dismutase ( $E C$ 1.15.1.1), an enzyme found in all aerobic tissues. The product of this reaction is hydrogen peroxide, but this too, together with any lipid hydroperoxides in tissues, is also actively metabolized to harmless end-products by glutathione peroxidase ( $E C$ 1.11.1.9). Two studies have suggested that the activity of this seleniumdependent enzyme is low in erythrocytes in some malnourished populations. Low Se levels in the soils in parts of Northern China have been associated with the cardiomyopathy known as Keshan disease (Chen et al. 1980) and others have suggested that 
low glutathione peroxidase activity may be important in the aetiology of kwashiorkor (Golden \& Ramdath, 1987).

In circumstances where superoxide and hydrogen peroxide may not be removed quickly enough, it is suggested that they can react together and produce the very reactive hydroxyl radical. Hydroxyl radicals will oxidize any organic molecule in its immediate vicinity by hydrogen abstraction and initiate peroxidation. The transition metals and especially ferrous-iron are powerful catalysts for this reaction. Polyunsaturated fatty acids (PUFA) are particularly vulnerable to such oxidation and lose hydrogen to form a lipid free radical. The subsequent oxidation of this compound and its reaction with other lipid molecules sets up the autocatalytic chain of lipid peroxidation (Halliwell \& Gutteridge, 1984).

\section{ANTIOXIDANTS AND LIPID PEROXIDATION}

There are two main defence systems against lipid peroxidation:

(1) by preventing initiation

(2) by preventing propagation.

Preventing initiation is primarily accomplished by maintaining the structure of tissues and cells and the architecture within the cell (Dormandy, 1983). In this respect several nutrients notably zinc and vitamins $\mathrm{A}$, B-complex and $\mathrm{C}$ can be considered preventive antioxidants in that deficiencies are associated with the breakdown of anatomic barriers. Second, divalent cations, particularly iron, are tightly compartmentalized or maintained in bound forms and the wide distribution of superoxide dismutase and glutathione peroxidase in aerobic tissues removes the substrates for hydroxyl radical formation. Third, damage to tissue by nutritional deficiencies, inflammation or other trauma disturbs this delicate organization and the body reacts with the acute-phase response, one of the functions of which is to scavenge the circulation for traces of Fe, other mineral ions and biologically active compounds (Koj, 1985).

Preventing radical propagation and chain elongation is the function of radicalquenching antioxidants. $\alpha$-Tocopherol, ascorbate and carotenes are the main ones obtained from the diet, but several others have also been identified in plasma: urate (Ames et al. 1981), protein-sulphydryl (Wayner et al. 1985) and albumin-bound bilirubin (Stocker et al. 1987). The extent to which protein is an antioxidant or a substrate is debatable for there are obviously some proteins which are damaged by free radical activity (Lunec et al. 1985). In addition, bilirubin (Stocker et al. 1987) and $\beta$-carotene (Burton \& Ingold, 1984) are more efficient antioxidants at low $\mathrm{O}_{2}$ tensions and may, therefore, be more important within the tissue than the plasma.

Riboflavin is the coenzyme to glutathione reductase $(E C$ 1.6.4.2) which is needed for the regeneration of glutathione (GSH). Intracellular $\mathrm{GSH}$ has radical-trapping properties (Halliwell \& Gutteridge, 1985), but is also the substrate for glutathione peroxidase. Thus, riboflavin deficiency may impair defences against both initiation and propagation of ROS, and may be particularly important in the mature erythrocyte which can no longer synthesize new components (Thurnham, 1985).

CHARACTERISTICS OF A CHAIN-BREAKING ANTIOXIDANT: CAROTENES

The important characteristics of a chain-breaking antioxidant are:

(1) that it will be more easily oxidized than other substrates in the immediate vicinity 
(2) that once oxidized it is relatively stable for its structure enables the instability, caused by the unpaired electron, to be distributed through the molecule.

It is widely accepted that $\alpha$-tocopherol (Fukuzawa et al. 1982) and ascorbate (Bielski, 1982) possess these properties, and carotenes too are similar but only at low $\mathrm{O}_{2}$ tensions similar to those that occur in the tissues. For example, Burton \& Ingold (1984) showed at an $\mathrm{O}_{2}$ pressure of 15 torr that $\beta$-carotene depressed the in vitro peroxidation of methyl linoleate by $42 \%$, although the $\beta$-carotene:lipid molar ratio was only $1: 23000$, however, at higher $\mathrm{O}_{2}$ pressures, it became a prooxidant. Other workers have also shown that $\beta$-carotene is very efficient at quenching singlet $O$ and disposing of the surplus energy as heat (Forman \& Fisher, 1981). It is important to note, however, that the characteristics of $\beta$-carotene should apply equally well to all carotenes as they all share the long chain of conjugated double bonds which enables the molecule to stabilize the unpaired electron. Thus, their function as antioxidants will be determined by their distribution in the tissues.

\section{MEASUREMENT OF ANTIOXIDANT CAPACITY}

Blood is in intimate contact with all tissues in the body and its antioxidant capacity is important in the supply and maintenance of tissue oxidants as well as removing prooxidants. Measurements of antioxidant status include individual analyses of micronutrient antioxidants as well as techniques to determine total antioxidant capacity for which there are two main types of methods.

Measurement of preventative antioxidants. Dormandy's group (Stocks et al. 1974) were the first to develop a method to measure total antioxidant capacity using a tissue preparation of ox brain in which the rate of malonaldehyde formation was used as the measure of oxidation. The important characteristic of tissue preparations is that initiation of lipid peroxidation is Fe-dependent and substances which bind or oxidize $\mathrm{Fe}$ will prevent or delay lipid peroxidation. Such methods have not been used to measure antioxidant capacity of malnourished populations, but in all groups studied by Stocks et al. (1974), caeruloplasmin and transferrin emerged as the major preventative antioxidants (Table 1) and tocopherol had little influence on the system.

The role of caeruloplasmin is to convert $\mathrm{Fe}^{2+}$ to $\mathrm{Fe}^{3+}$ (Gutteridge, 1986) and that of transferrin to bind free $\left(\mathrm{Fe}^{3+}\right) \mathrm{Fe}$ (Stocks et al. 1974). In the acute-phase response, caeruloplasmin concentrations increase from 30 to $60 \%$ and both total transferrin concentrations and the Fe bound to transferrin fall (Bothwell et al. 1979; Fleck \& Myers, 1985). The lower level of $\mathrm{Fe}^{3+}-\mathrm{Fe}$ saturation may promote $\mathrm{Fe}$ uptake from ferritin by hepatocytes (Sibille et al. 1989). In children dying of kwashiorkor, however, transferrin concentrations are reported to be less than $33 \%$ of normal and the percentage saturation with Fe to be above normal (McFarlane et al. 1970).

Schelp et al. (1981) have suggested that several markers of the acute-phase response are increased in malnourished populations, and Table 2 illustrates the effects of different diseases on caeruloplasmin which we found to be increased in underweight Nigerian children with malaria and upper respiratory tract infections (Thurnham et al. 1988a) to levels similar to those found in adult rheumatoid patients (Gutteridge, 1986). In Thai adults with malaria, however, only a very slight increase was seen in the rural patients and none in urban patients compared with their respective controls (Thurnham et al. 1990). 
Table 1. Changes in plasma antioxidants which may function to prevent lipid peroxidation (From Bothwell et al. (1979); Koj (1985); Behring data sheets (1987))

\begin{tabular}{|c|c|c|c|}
\hline Antioxidant & Normal range & Function & $\begin{array}{l}\text { Alteration in response to } \\
\text { trauma }\end{array}$ \\
\hline Cacruloplasmin (g/l) & $0.155-0.592$ & $\mathrm{Fe}^{2+}$ to $\mathrm{Fe}^{3+}$ & Increase $30-60 \%$ \\
\hline $\begin{array}{l}\text { Transferrin: } g / 1 \\
\qquad \mu \mathrm{mol} / 1\end{array}$ & $\begin{array}{l}1 \cdot 9-2 \cdot 58 \\
25-34\end{array}$ & Bind $\mathrm{Fe}^{3+}$ & Reduction $30 \%$ \\
\hline $\begin{array}{l}\text { Ferritin: } \mu \mathrm{g} / 1 \\
\mathrm{nmol} / 1\end{array}$ & $\begin{array}{c}15-250 \\
0.034-0.562\end{array}$ & Bind $\mathrm{Fe}^{2+}$ & $\begin{array}{r}\text { Increase to: } 3000 \mu \mathrm{g} / 1 \\
6.7 \mathrm{nmol} / 1\end{array}$ \\
\hline $\begin{array}{l}\text { Haptoglobin: } \mathrm{g} / \mathrm{l} \\
\qquad \mu \mathrm{mol} / 1\end{array}$ & $\begin{array}{r}0.703-3 \cdot 79 \\
7 \cdot 0-37.9\end{array}$ & Bind hacmoglobin & Increase $200-500 \%$ \\
\hline Haemopexin $(\mathrm{g} / \mathrm{l})$ & $0 \cdot 513-1 \cdot 14$ & Bind haem & No change \\
\hline Ascorbate $(\mu \mathrm{mol} / /)$ & $11-80$ & $\mathrm{Fe}^{3+}$ to $\mathrm{Fe}^{2+}$ & Reduction \\
\hline
\end{tabular}

Table 2. Caeruloplasmin $(\mathrm{g} / \mathrm{l})$ in various groups

\begin{tabular}{|c|c|c|c|}
\hline & Group studied & Median & Range \\
\hline UK & $\begin{array}{l}\text { Control subjects* } \\
\text { Rheumatoid patients* } \\
\text { Control subjects } \dagger\end{array}$ & $\begin{array}{l}0.255 \\
0.470 \\
0.293\end{array}$ & $\begin{array}{l}0.10-0.42 \\
0.30-0.64 \\
0.23-0.341\end{array}$ \\
\hline Nigerian & $\begin{array}{l}\text { Upper respiratory tract and other infections } \dagger \\
\text { Malaria } \dagger\end{array}$ & $\begin{array}{l}0.503 \\
0.444\end{array}$ & $\begin{array}{l}0.355-0.566 \\
0.293-0.592\end{array}$ \\
\hline Thait & $\begin{array}{c}\text { Urban: Controls } \\
\text { Malaria } \\
\text { Rural: Controls } \\
\text { Malaria }\end{array}$ & $\begin{array}{l}0.234 \\
0.26 \\
0.249 \\
0.281\end{array}$ & $\begin{array}{l}0.219-0.256 \\
0.222-0.298 \\
0.192-0.298 \\
0.241 \sim 0.336\end{array}$ \\
\hline
\end{tabular}

\footnotetext{
* Gutteridge (1986).

† Thurnham et al. (1988a).

$\ddagger$ Thurnham et al. 1990 .
}

Ferritin is also an acute-phase protein, and plasma concentrations increase in infection and can remain high for several weeks (Birgegard. 1980), which complicates its usual clinical use as a marker of Fe stores when high values indicate Fe overload (Worwood, 1977). High plasma ferritins are reported in malnourished Jamaican (Golden et al. 1986) and Indian children (Srikantia, 1958) and Golden \& Ramdath (1987) noted that eight of nine children who died following admission with kwashiokor, had high plasma ferritins $(>250 \mu \mathrm{g} / \mathrm{l}(0.56 \mathrm{nmol} / \mathrm{l})$ five times the normal range) and low erythrocyte glutathione peroxidase activities $(<17 \mathrm{U} / \mathrm{g}$ haemoglobin). They suggested that treatment of such children might be improved by chelator chemotherapy, the inference being that high ferritins indicated Fe overload. However, more recent studies have suggested that the percentage of non-glycosylated ferritin was higher (33-49\%; Hudson, 1987) than that reported by Birgegard $(1980 ; 20 \%)$ suggesting that some of the ferritin at least, represented liver damage. Unfortunately, the number of Jamaican children in this second study was small and none had the high ferritin concentrations associated with the high mortality in the earlier report.

We have also reported elevated ferritin levels in Nigerian children in an area where 


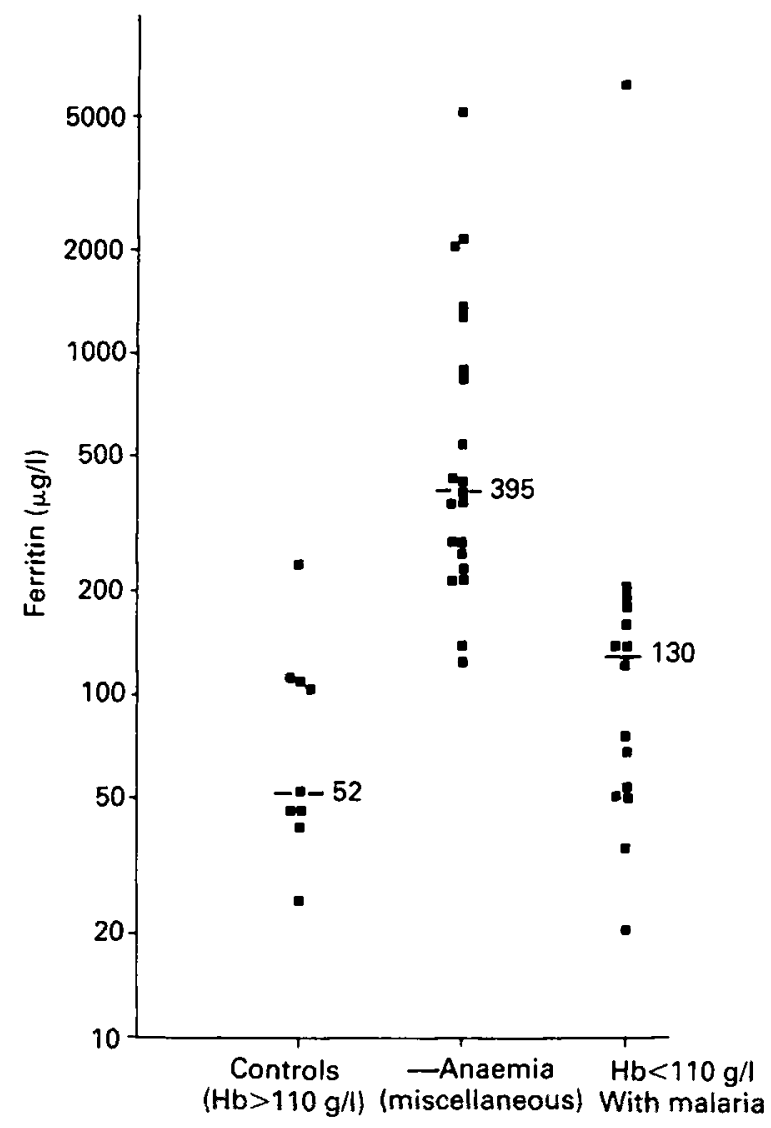

Fig. 1. Plasma ferritin values in Nigerian children with anaemia. Forty-six children aged 1-12 years of both sexes presenting at Obafemi Awolowo University Teaching Complex, Ile Ife, Nigeria were separated into those with anaemia (hacmoglobin $(\mathrm{Hb})<110 \mathrm{~g} / \mathrm{l}$ ) and by the presence of malaria into the three groups shown. Values taken from Adelekan \& Thurnham (1990).

malnutrition and infection are found (Adelekan \& Thurnham, 1990). Fig. 1 shows plasma ferritin levels in Nigerian children who were grouped on the basis of their haemoglobin levels and the presence or absence of malaria. Thalassaemia and the associated Fe-overload was not suspected in these children but the very high ferritin concentrations probably arise both from increased synthesis and some liver damage, since malaria prevalence is high in this area and all those children with anaemia may have had a recent attack. A single explanation to interpret plasma ferritin in such populations is most unlikely.

Haptoglobin is a further acute-phase protein showing a two- to fivefold increase with infection (Koj, 1985), the function of which is to assist the uptake of haemoglobin by the reticulo-endothelium for the re-utilization of Fe. Haemopexin is an acute-phase protein which binds equimolar amounts of haem and other haemoproteins such as myoglobin and cytochrome C, but increases little if anything in infection (Koj, 1985). In contrast to ferritin, however, it would appear that the capacity to produce haptoglobin can be exhausted in populations exposed to excessive haemolysis. Workers have shown that the proportion of persons in West African populations with no detectable haptoglobin in 
their circulation can be as high as $48 \%$ and is positively correlated with malaria endemicity (Trape \& Fribourg-Blanc, 1988; Rougemont et al. 1988). Furthermore, the inability to produce sufficient haptoglobin would not appear to be related to parasitaemia or malnutrition since both these would occur in the younger age-groups, whereas prevalence of ahaptoglobinaemia was greatest in 10 to 14-year-old children in a zone of intermediate malaria intensity (Trape \& Fribourg-Blanc, 1988). It is conceivable that ahaptoglobinaemia could be of pathological significance in malaria since haemoglobin is known to promote the autoxidation of lipids (Stocks et al. 1971), thus, free haemoglobin in plasma may promote autoxidation of lipid in vivo and magnify still further the oxidative stresses on the host (D. I. Thurnham, D. Kwiatkowski, B. M. Greenwood and A. Hill, unpublished results).

\section{RADICAL QUENCHING ANTIOXIDANTS}

Wayner et al. $(1985,1987)$ devised a method for measuring total radical trapping capacity (TRAP) in plasma or serum. The measurement of TRAP is fundamentally different from the techniques used by Stocks et al. (1974) and measures the ability of plasma or other biological fuids to prevent lipid peroxidation initiated by the thermal decomposition of a water-soluble azo compound 2,2'-azo-bis-(2-amidinopropane hydrochloride) (ABAP; Polysciences Ltd, Northampton, UK). This reaction is Fe-independent and is not inhibited by Fe-chelating materials but is quenched by substances which will quench free radicals.

TRAP capacity in plasma is mainly due to four components, $\alpha$-tocopherol, ascorbate, urate and the sulphydryl content of protein (Wayner et al. 1985, 1987; Thurnham et al. 1987). In addition, carotenes (Burton \& Ingold, 1984) and bilirubin (Stocker et al. 1987) can also trap lipid free radicals but their efficiency is improved at low $\mathrm{O}_{2}$ tensions similar to those found in tissues. The amounts of these components in blood are shown in Table 3 together with their relative trapping efficiencies as obtained in the TRAP assay (Koottathep, 1988). It can be seen that in terms of concentration, proteins are the largest single component in plasma, but if trapping efficiency is taken into account then urate has the largest capacity.

\section{USE OF TRAP ASSAY IN MALNOURISHED POPULATIONS}

We have used this assay on plasma from undernourished Nigerian children some of whom had malaria and others who had upper respiratory tract infections and possibly also asymptomatic malaria (Thurnham et al. 1988a). Table 4 shows the concentrations of radical-trapping antioxidants in the blood of the children and healthy Caucasian adults. Concentrations of the main radical-trapping antioxidants, i.e. urate and proteinsulphydryl were very similar in all three groups (Thurnham et al. 1988a), however, when we measured peroxyl-radical trapping (TRAP) capacity, we found abnormally low values associated with malaria. Fig. 2 shows measured TRAP values $v$. those calculated from the individual components in plasma from healthy Caucasian adults, for which the agreement is generally good (Thurnham et al. 1987); however, with blood from malaria-infected patients, there are large discrepancies, with experimental TRAP values being lower than calculated values (Thurnham et al. 1988a; Thurnham, 1988). The reason for these discrepancies is now believed to be due to the presence of prooxidant 
Table 3. Radical trapping capacity

\begin{tabular}{|c|c|c|c|c|}
\hline \multirow[b]{3}{*}{ Antioxidant } & \multirow{3}{*}{$\begin{array}{l}\text { Plasma concentration } \\
\qquad(\mu \mathrm{mol} / 1)\end{array}$} & \multicolumn{3}{|c|}{ Radical trapping } \\
\hline & & \multirow[b]{2}{*}{ Efficiency* } & \multicolumn{2}{|c|}{ Capacityt (\%) } \\
\hline & & & Mean & SD \\
\hline Tocopherol & $11-50$ & $\times 2$ & 8 & 2 \\
\hline Ascorbate & $11-100$ & 1.5 & 16 & 4 \\
\hline Urate & $120-420$ & $1 \cdot 7$ & 58 & 3 \\
\hline Protein-sulphydryl & $353-700$ & $0 \cdot 2$ & 18 & 5 \\
\hline Bilirubin & $5-17$ & 2 & \multicolumn{2}{|c|}{ - } \\
\hline Carotene: UK & $1 \cdot 43-2 \cdot 65$ & $?$ & \multirow{2}{*}{\multicolumn{2}{|c|}{ 一 }} \\
\hline Nigeria & up to 30.0 & & & \\
\hline
\end{tabular}

* Trapping efficiencies reported by Koottathep (1988), except bilirubin (Stocker et al. 1987).

$\uparrow$ Capacities reported by Thurnham et al. (1987).

Table 4. Radical-trapping antioxidants in plasma from Nigerian children and Caucasian adults ( $\mu$ molll $)^{*}$

(Medians and ranges; no. of subjects in parentheses)

\begin{tabular}{llcccc}
\hline \hline Group & & Tocopherol & Ascorbate & Urate & $\begin{array}{c}\text { Protein- } \\
\text { sulphydryl }\end{array}$ \\
\hline Malaria cases $(n 11):$ & Median & $11 \cdot 1$ & $2 \cdot 1$ & 240 & 585 \\
& Range & $5 \cdot 3-17 \cdot 1$ & $0-127 \cdot 5$ & $65-538$ & $346-868$ \\
Other diseases $(n 10):$ & Median & $13 \cdot 7$ & 0 & 210 & 551 \\
& Range & $3 \cdot 4-47 \cdot 6$ & $0-20 \cdot 2$ & $150-287$ & $419-971$ \\
Caucasian adults $(n$ 20): & Median & $25 \cdot 1$ & $69 \cdot 5$ & 281 & 574 \\
& Range & $16 \cdot 0-36 \cdot 0$ & $22 \cdot 5-96 \cdot 5$ & $353-684$ & $480-970$ \\
\hline \hline
\end{tabular}

* Values from Thurnham et al. (1988a).

activity in many malaria samples which depletes antioxidant capacity once linoleic acid is added and before the samples even reach the electrode chamber. Using a modified TRAP assay, it has been possible to show that many malaria plasma linoleic acid mixtures will spontaneously initiate $\mathrm{O}_{2}$ uptake in the absence of the water-soluble, free radical initiator. This is discussed in a separate communication at this meeting (Thurnham \& Kwiatkowski, 1990).

\section{PHYSIOLOGICAL SIGNIFICANCE OF PLASMA ANTIOXIDANTS}

The physiological importance of preventive antioxidants seems certain since there are active changes associated with disease or trauma which occur to cope with the increased risk of lipid peroxidation. In contrast, the radical trapping capacity of different antioxidants in a physiologically active system may bear no relation to their functions in vivo. The concentration of $\alpha$-tocopherol, for example, is frequently lower in malnourished populations by comparison with those in the West. Table 5 shows lower concentrations of $\alpha$-tocopherol in Chinese adults (Thurnham et al. 1988b) compared with 


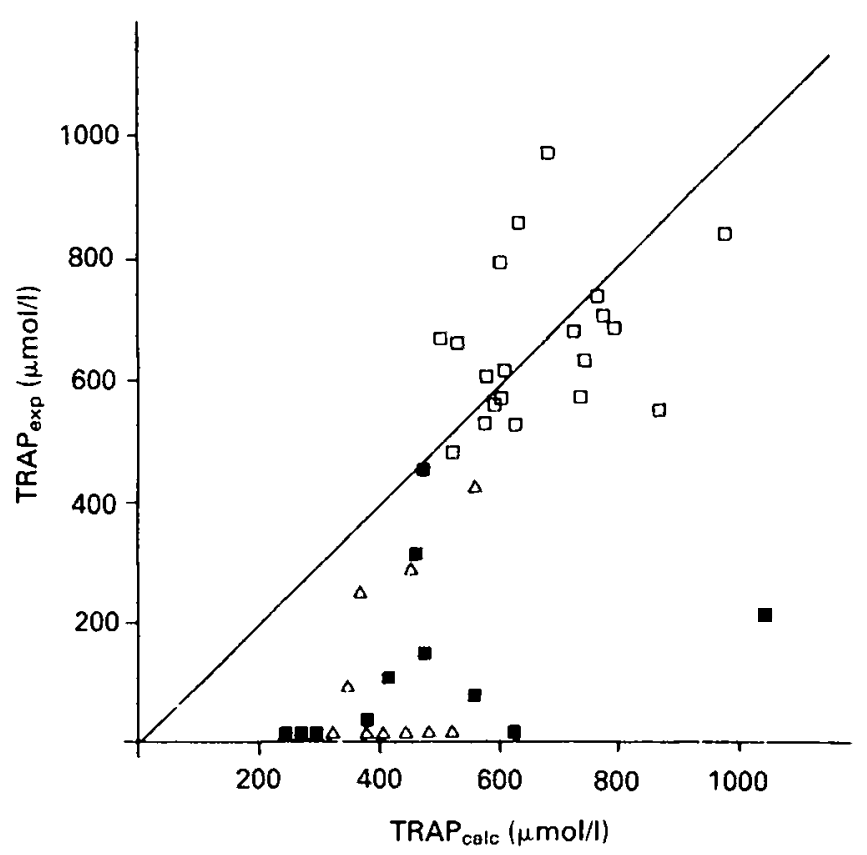

Fig. 2. Experimentally determined and calculated total radical trapping capacity $\left(T_{R A P} P_{\text {exp }}\right.$ and $T_{R A P} P_{\text {calc }}$ respectively) activities in plasma from Nigerian children and Caucasian adults. TRAP ${ }_{\text {exp }}$ was measured by the method of Wayner et al. (1987) and TRAP ${ }_{\text {calc }}$ values obtained by summation of the individual antioxidant concentrations multiplied by the respective trapping efficiencies reported by the same authors. Values for Nigerian children with malaria $(\square)$ or other infections $(\triangle)$ (Thurnham et al. 1988a) and Caucasian aduits $(\square)$ (Thurnham et al. 1987).

those measured in people of a similar age in Great Britain (unpublished results). Horwitt et al. (1972) pointed out that the concentration of $\alpha$-tocopherol in plasma is dependent on the lipid concentration of the individual lipid classes. The correlation with cholesterol is greatest (Thurnham et al. 1986) and when one examines the tocopherol:cholesterol ratio, the difference between the two populations disappears. That is, the level of $\alpha$-tocopherol in each individual is adjusted to that individual's level of circulating lipid. Furthermore, the tocopherol:cholesterol molar ratio in human plasma is very similar to that of tocopherol:PUFA $(1: 220)$ in lipid structures within the cell in the rat (Fukuzawa et al. 1982), suggesting a structural or physiological requirement.

Plasma concentrations of ascorbate also vary widely between individuals and are frequently low in malnourished communities and during infection (Irwin \& Hutchins, 1976). It is interesting to consider how this affects the antioxidant capacity of the plasma. It has been suggested that ascorbate is necessary to reduce the $\alpha$-tocopheryl radical back to tocopherol to maintain it in a functional form as a lipid antioxidant (Packer et al. 1979). In vivo, dehydroascorbate can traverse the erythrocyte membrane and ascorbate can be regenerated to maintain the antioxidant capacity of the plasma (Orringer \& Roer, 1979). Thus, the TRAP assay does not assess the physiological radical-trapping capacity since erythrocytes are not present and, in vitro, this cannot be tested using the TRAP assay since incorporating any erythrocytes is likely to cause haemolysis and trigger 
Table 5. $\alpha$-Tocopherol and tocopherol:cholesterol ratios

(Mean values with their standard errors)

\begin{tabular}{|c|c|c|c|c|c|c|c|c|}
\hline & \multicolumn{4}{|c|}{ China* } & \multicolumn{4}{|c|}{ Great Britaint } \\
\hline & \multicolumn{2}{|c|}{$\begin{array}{c}\alpha \text {-Tocopherol } \\
(\mu \mathrm{mol} / \Lambda)\end{array}$} & \multicolumn{2}{|c|}{$\begin{array}{c}\text { Ratio } \\
(\mu \mathrm{mol} / \mathrm{mmol})\end{array}$} & \multicolumn{2}{|c|}{$\begin{array}{c}\alpha \text {-Tocopherol } \\
(\mu \mathrm{mol} / \mathrm{l})\end{array}$} & \multicolumn{2}{|c|}{$\begin{array}{c}\text { Ratio } \\
(\mu \mathrm{mol} / \mathrm{mmol})\end{array}$} \\
\hline & Mean & SE & Mean & SE & Mean & $\mathrm{SE}$ & Mean & $\mathrm{SE}$ \\
\hline Men & $17 \cdot 53$ & 0.272 & $5 \cdot 35$ & 0.067 & 27.07 & 0.294 & 4.65 & 0.037 \\
\hline$n$ & \multicolumn{2}{|c|}{286} & \multicolumn{2}{|c|}{286} & \multicolumn{2}{|c|}{939} & \multicolumn{2}{|c|}{932} \\
\hline Women & 18.45 & 0.267 & $5 \cdot 36$ & 0.065 & $26 \cdot 23$ & 0.278 & $4 \cdot 56$ & 0.037 \\
\hline$n$ & \multicolumn{2}{|c|}{298} & \multicolumn{2}{|c|}{298} & \multicolumn{2}{|c|}{938} & \multicolumn{2}{|c|}{925} \\
\hline
\end{tabular}

* From Thurnham et al. (1988b).

$\dagger$ Values from The Nutrition Survey of Adults in Great Britain 1986-7, Gregory et al. (1990).

immediate autoxidation. Thus, the level of ascorbate in plasma which may compromise radical quenching is unknown.

Furthermore, ascorbate can also be a prooxidant, notably in the presence of Fe which it reduces to the ferrous form. Free $\mathrm{Fe}$ is not normally present in blood plasma but, as already discussed, there is indirect evidence that it can appear. Frei et al. (1988) recently reported that stimulating polymorphonuclear leukocytes in plasma resulted in a very rapid oxidation of ascorbate. I suggest the reasons for this may be twofold: it removes a potential prooxidant from the plasma which could promote hydroxyl radical production in an uncontrolled fashion, and second, it is reported that the reaction of superoxide produced by the neutrophils with ascorbate doubles the amount of $\mathrm{H}_{2} \mathrm{O}_{2}$ available to the myeloperoxidase system (compared with superoxide alone) for generation of hypochlorous acid (Thomas et al. 1988). That is, the presence of ascorbate may increase the effectiveness of phagocytic action in the microenvironment surrounding the phagocyte, but in the macroenvironment of the whole vasculature in disease it may promote $\mathrm{Fe}^{2+}$ formation. Circulating levels of ascorbate in disease may be physiologically reduced to prevent this (Table 1).

Many of the antioxidant properties of ascorbate are shared by urate and Ames et al. (1981) suggest that the high levels of urate in man have evolved to replace some of man's dependence on ascorbate because of the latter's prooxidant functions. Urate is synthesized from purines and there is some evidence to suggest that circulating levels increase in response to oxidative stress: e.g. in exercise and high alcohol ingestion, and we have observed increased levels in severe malaria (D. I. Thurnham, D. Kwiatkowski, B. M. Greenwood and A. Hill, unpublished results).

\section{RIBOFLAVIN}

Finally I should say a few words about riboflavin for riboflavin status is frequently poor in Third World countries and mainly, it is believed, for the lack of dairy products in the diet (Bates, 1987). Riboflavin is only indirectly related to antioxidant function through its role as a coenzyme for the enzyme glutathione reductase. That is, riboflavin deficiency may impair the regeneration of GSH and so compromise the activity of glutathione 
peroxidase. Golden \& Ramdath (1987) reported reduced levels of erythrocyte GSH in oedematous malnutrition, i.e. those where there may have been some concurrent free radical stress but the riboflavin status of these children was not reported. We examined the possibility that riboflavin deficiency might impair the ability of the cell to withstand oxidant stress and cause erythrocyte lysis, both experimentally in rats using malaria as the source of oxidant stress and by observations on human malaria (Thurnham, 1985; Das et al. 1988). Both findings supported the suggestion that the more severe the deficiency of riboflavin, the less able erythrocytes were to maintain parasite growth and the lower were the parasitaemias. The benefit of this observation, however, is questionable as all riboflavin-deficient rats died despite undetectable parasite numbers in some cases. In addition, the mechanism by which riboflavin deficiency suppresses parasite numbers is still far from clear (Dutta et al. 1989), but the field is of great potential interest as riboflavin analogues have been shown to have antimalarial properties (Cowden et al. 1988).

\section{CONCLUSIONS}

In conclusion, it is important to realise that there are many antioxidant substances in blood but that these can be divided into those which prevent initiation of lipid peroxidation by interfering with the availability of $\mathrm{Fe}^{2+}$ or of other Fe products and those which are able to quench free radicals and reduce the extent of peroxidative damage.

Levels of preventative antioxidants such as caeruloplasmin, ferritin and haptoglobin are usually increased in association with disease and as the prevalence of diseases is usually high in malnourished populations, it is not uncommon to find these proteins also raised. Thus the usefulness of ferritin as an indicator of Fe stores has to be carefully questioned in such populations.

Levels of haptoglobin have been shown to be abnormally low in large numbers of people in areas of high malaria endemicity and ahaptoglobinaemia may be of importance in malaria pathogenesis as haemoglobin is a powerful promotor of lipid autoxidation.

Measurements of total radical trapping capacity in plasma is of questionable physiological significance since levels of the individual antioxidants may be 'tuned' to meet individual requirements. Hence, concentrations of $\alpha$-tocopherol are adjusted to the level of circulating lipid. Plasma ascorbate in health is probably regenerated from dehydroascorbate within the erythrocyte, so absolute concentrations may be of little relevance to function and in a sick person may be depressed to prevent prooxidant functions of ascorbate.

Riboflavin may be important in the maintenance of intracellular reduced glutathione levels. By this manner, riboflavin deficiency may increase erythrocyte susceptibility to oxidant stress and the subsequent lysis be responsible for the suppression of parasite numbers in malaria.

\section{REFERENCES}

Adelekan, D. A. \& Thurnham, D. I. (1990). Plasma ferritin concentrations in anemic children: the relative importance of malaria, riboflavin deficiency and other infections. American Journal of Clinical Nutrition 51 , $453-456$.

Ames, B. N.. Cathcart, R., Schwiers, E. \& Hochstein, P. (1981). Uric acid provides an oxidant defense in humans against oxidant- and radical-causing aging and cancer: a hypothesis. Proceedings of the National Academy of Sciences, USA 78, 6858-6862. 
Baboire, M. B. (1973). Oxygen dependent microbial killing of phagocytes. New England Journal of Medicine 298, 659-680.

Bates, C. J. (1987). Human riboflavin requirements, and metabolic consequences of deficiency in man and animals. World Review of Nutrition and Dietetics 50, 215-265.

Bielski, B. H. (1982). Chemistry of ascorbic acid radicals. In Ascorbic acid, Chemistry, Metabolism and Uses, pp. 81-100 [P. A. Sieb and B. M. Tolbert, editors]. Washington: American Chemical Society.

Birgegard, G. (1980). The source of serum ferritin during infection. Studies with concanavalin A-Sepharose absorption. Clinical Science 59, 385-387.

Blake, D. R., Merry, P., Unsworth, J., Kidd, B. L., Outhwaite, J. M., Ballard, R. Morris, C. J., Grey, L. \& Lunec, J. (1989). Hypoxic-reperfusion injury in the inflamed human joint. Lancet $\mathbf{1}, 289-293$.

Bothwell, T. H., Charlton, R. W., Cook, J. D. \& Finch, C. A. (editors) (1979). Plasma iron. In Iron Metabolism in Man, pp. 284-310. Oxford: Blackwell.

Burton, G. W. \& Ingold, K. U. (1984). B-carotene: an unusual type of lipid antioxidant. Science 224, 569-573.

Chen, X., Yang, G., Chen, J., Chen, X., Wen, Z. \& Ge, K. (1980). Studies on the relations of selenium and Keshan disease. Biological Trace Element Research 2, 91-107.

Clark, I. A., Chaudhri, G. \& Cowden, W. B. (1989). Some roles of free radicals in malaria. Free Radical Biology \& Medicine 6, 315-321.

Cowden, W. B., Clark, I. A. \& Hunt, N. H. (1988). Flavins as potential antimalarials. 1. 10-(halophenyl)-3methylflavins. Journal of Medicinal Chemistry 31, 799-801.

Das, B. S., Das, D. B., Satpathy, R. N., Patnaik, J. K. \& Bose, T. K. (1988). Riboflavin deficiency and severity of malaria. European Journal of Clinical Nutrition 42, 277-283.

Dormandy, T. L. (1983). An approach to free radicals. Lancet ii, 1010-1014.

Dutta, P., Gee, M., Rivlin, R. S. \& Pinto, J. (1989). Riboflavin deficiency and glutathione metabolism in rats: possible mechanisms underlying altered responses to hemolytic stimuli. Journal of Nutrition 118, 1149 1157.

Fleck, A. \& Myers, M. A. (1985). Diagnostic and prognostic significance of the acute phase proteins. In The Acute Phase Response to Injury and Infection, pp. 249-271 [A. H. Gordon and A. Koj, editors]. Amsterdam: Elsevier Science Publishers.

Forman, H. J. \& Fisher, A. B. (1981). Antioxidant defences. In Oxygen and Living Processes: an Interdisciplinary Approach, pp. 236-249 [D. A. Gilbert, editor]. New York: Springer-Verlag.

Frei, B., Stocker, R. \& Ames, B. N. (1988). Antioxidant defenses and lipid peroxidation in human blood plasma. Proceedings of the National Academy of Sciences, USA 85, 9748-9752.

Fukuzawa, K., Tokumura, A., Ouchi, S. \& Tsukatani, H. (1982). Antioxidant activities of tocopherols on $\mathrm{Fe}^{2+}$-ascorbate-induced lipid peroxidation in lecithin liposomes. Lipids 17, 511-513.

Gey, K. F. (1986). On the antioxidant hypothesis with regard to arteriosclerosis. Bibliotheca Nutritio Dieta 37, 53-91.

Golden, M. H. N., Golden, B. E. \& Bennett, F. I. (1986). High ferritin values in malnourished children. In Trace Elements in Man and Animals, pp. 775-779 [C. F. Mills, I. Bremner and J. H. Chesters, editors]. Slough: Commonwealth Agricultural Bureaux.

Golden, M. H. N. \& Ramdath, D. (1987). Free radicals in the pathogenesis of kwashiorkor. Proceedings of the Nutrition Society 46, 53-68.

Gregory, J., Foster, K., Tyler, H. A. \& Wiseman, M. (1990). A Dietary and Nutritional Survey of British Adults. London: H.M. Stationery Office.

Gutteridgc, J. M. C. (1986). Antioxidant properties of the proteins caeruloplasmin, albumin and transferrin. A study of their activity in serum and synovial fluid from patients with rheumatoid arthritis. Biochimica et Biophysica Acta 869, 119-127.

Halliwell, B. \& Gutteridge, J. M. C. (1984). Oxygen toxicity, oxygen radicals, transition metals and disease. Biochemical Journal 219, 1-14.

Halliwell, B. \& Gutteridge, J. M. C. (editors) (1985). Free Radicals in Biology and Medicine. Oxford: Clarendon Press.

Harman, D. (1984). Free radical theory of aging: the 'free radical' diseases. Age 7, 111-131.

Horwitt, M. K., Harvey, C. C., Dahm, C. H. \& Searcy, M. T. (1972). Relationship between tocopherol and serum lipid levels for determination of nutritional adequacy. Annals of the New York Academy of Sciences 203, 223-236.

Hudson, M. A. (1987). Iron in malnutrition. MSc Thesis, University of the West Indies.

Irwin, M. I. \& Hutchins, B. K. (1976). A conspectus of research on vitamin C requirements of man. Journal of Nutrition 106, 821-879. 
Koj, A. (1985). Definition, classification and biological functions of acute phase proteins. In The Acute Phase Response to Injury and Infection, pp. 139-158 [A. H. Gordon and A. Koj, editors]. Amsterdam: Elsevier Science Publishers.

Koottathep, S. (1988). Studies on chain-breaking antioxidants. MSc Thesis, University of Birmingham.

Lunec, J., Blake, D. R., McCleary, S. J., Brailsford, S. \& Bacon, P. A. (1985). Self-perpetuating mechanisms of Immunoglobulin $\mathrm{G}$ aggregation in rheumatoid inflammation. Journal of Clinical Investigation $\mathbf{7 6}$, 2084-2090.

McFarlane, H., Reddy, S., Adcock, K. J., Adeshina, H., Cooke, A. R. \& Akene, J. (1970). Immunity, transferrin, and survival in kwashiokor. British Medical Journal 4, 268-270.

Orringer, E. P. \& Roer, M. E. S. (1979). An ascorbate-mediated transmembrane-reducing system of the human erythrocyte. Journal of Clinical Investigation 63, 53-58.

Packer, J. E., Slater, T. F. \& Willson, R. L. (1979). Direct observations of a free-radical interaction between vitamin $E$ and vitamin C. Nature 278, 737-738.

Rougemont, A., Dumbo, O., Bouvier, M., Soula, G., Perrin, L., Tamoura, B., Yerly, S., Dolo, A., Brenner. E., Kodio, B., Srivastava, I. \& Ranque, E. (1988). Hypohaptoglobinaemia as an epidemiological indicator and clinical indicator for malaria. Lancet ii, 709-712.

Schelp, F. P., Pongpaew, P., Sutjahjo, S. R., Supawan, V., Saovakontha, S. \& Migasena, P. (1981). Proteinase inhibitors and other biochemical criteria in infants and primary schoolchildren from urban and rural environments. British Journal of Nutrition 45, 451-459.

Sherlock, S. (1986). The spectrum of hepatotoxicity due to drugs. Lancet ii, 440-444.

Sibille, J.-C., Kondo, H. \& Aisen, P. (1989). Uptake of ferritin and iron bound to ferritin by rat hepatocytes: modulation by apotransferrin, iron chelators and chloroquin. Biochimica et Biophysica Acta 1010, $204-209$.

Slater, T. F. (1984). Free radical mechanisms in tissue injury. Biochemical Journal 222, 1-15.

Srikantia, S. G. (1958). Ferritin in nutritional oedema. Lancet i, 667-668.

Stocker, R., Yamamoto, Y., McDonagh, A. F., Glazer, A. N. \& Ames, B. N. (1987). Bilirubin is an antioxidant of possible physiological importance. Science 235, 1043-1046.

Stocks, J., Kemp, M. \& Dormandy, T. L. (1971). Increased susceptibility of red blood-cell lipids to autoxidation in haemolytic states. Lancet i, 266-269.

Stocks, J., Gutteridge, J. M. C., Sharp, R. J. \& Dormandy, T. L. (1974). Assay using brain homogenate for measuring the antioxidant activity of biological fluids. Clinical Science \& Molecular Medicine 47, $215-222$.

Thomas, E. L., Learn, D. B., Jefferson, M. M. \& Weatherred, W. (1988). Superoxide-dependent oxidation of extracellular reducing agents by isolated neutrophils. Journal of Biological Chemistry 263, 2178-2186.

Thurnham, D. I. (1985). Nutrient deficiencies and malaria: a curse or a blessing? In Proceedings of XIIIth International Congress of Nutrition, pp. 129-131 [T. G. Taylor and N. K. Jenkins, editors]. London: Libbey.

Thurnham, D. 1. (1988). Vitamin C (ascorbic acid): Antioxidant functions of vitamin C in disease in man and animals. In Comparative Nutrition, pp. 91-103 [K. Blaxter and I. Macdonald, editors]. London: Libbey.

Thurnham, D. I., Davies, J. A., Crump, B. J., Situnayake, R. D. \& Davis, M. (1986). The use of different lipids to express serum tocopherol:lipid ratios for the measurement of vitamin $\mathrm{E}$ status. Annals of Clinical Biochemistry 23, 514-520.

Thurnham, D. I., Koottathep. S. \& Adelekan, D. A. (1988a). Chain-breaking antioxidants in the blood of malaria-infected Nigerian children. In Free Radicals: Chemistry and Medicine, pp. 161-185 [C. Ricc-Evans and T. Dormandy, editors]. London: Richelieu Press.

Thurnham, D. I. \& Kwiatkowski, D. (1990). A modified TRAP assay to measure pro-oxidant activity in serum. Proceedings of the Nutrition Society 49, 22A.

Thurnham, D. I., Munoz, N., Lu, J. B., Wahrendorf, J., Zheng, S.-F., Hambidge, K. M. \& Crespi, M. $(1988 b)$. Nutritional and haematological status of Chinese farmers: the influence of 13.5 months treatment with riboflavin, retinol and zinc. European Journal of Clinical Nutrition 42, 647-660.

Thuirnham, D. I., Singkamani, R., Kaewichit, R. \& Wongworapat, K. (1990). Influence of malaria infection on peroxyl-radical trapping capacity in plasma from rural and urban Thai adults. British Journal of Nutrition 64, 257-271.

Thurnham, D. I., Situnayake, R. D., Koottathep, S., McConkey, B. \& Davis, M. (1987). Antioxidant status measured by the 'TRAP' assay in rheumatoid arthritis. In Free Radicals, Oxidant Stress, and Drug Action, pp. 169-191 [C. Rice-Evans, editor]. London: Richelieu Press.

Trape, J. F. \& Fribourg-Blanc, A. (1988). Ahaptoglobinemia in African populations and its relation to malaria endemicity. American Journal of Epidemiology 127, 1282-1288. 
Wayner, D. D. M., Burton, G. W., Ingold, K. U. \& Locke, S. (1985). Quantitative measurement of the total peroxyl radical-trapping antioxidant capability of human blood plasma by controlled lipid peroxidation. FEBS Letters 187, 33-37.

Wayner, D. D. M., Burton, G. W., Ingold, K. U., Barklay, L. R. C. \& Locke, S. (1987). The relative contributions of vitamin $\mathrm{E}$, urate, ascorbate and proteins to the total peroxyl radical-trapping antioxidant activity of human blood plasma. Biochimica et Biophysica Acta 92, 408-419.

Worwood, M. (1977). The clinical biochemistry of iron. Seminars in Haematology 14, 3-30. 